\title{
Are hemoglobin and volume oxygen maximum (vo2max) relevant each other?
}

\author{
Isti Dwi Puspita Wati \\ Universitas Tanjungpura, Indonesia
}

Received: 17 January 2021; Accepted 23 April 2021; Published 22 July 2021

Ed 2021; 6(2): 193-200

\begin{abstract}
The support for recording achievements in sports achievements, two of which are the ability to enter oxygen $\left(\mathrm{O}_{2}\right)$ into the lungs and further the ability to take up this oxygen so that it can be utilized in the process of providing energy. The second function of $\mathrm{O} 2$ is to transport carbon dioxide (CO2) through respiration. These two processes are carried out simultaneously at least between the respiratory cycle and its close relationship with hemoglobin. Hemoglobin is part of the blood which has a function to bind $\mathrm{O} 2$ and $\mathrm{CO} 2$ at the end in the process of respiration. The purpose of this study was to determine evidence of a relationship between HB and VO2max. This research is a descriptive correlational study. Samples are sports athletes who are preparing for Pre PAPUA. The number of samples was 83 athletes in the game group consisting of sand volleyball (6), badminton (17), Petanque (12), table tennis (13), and Futsal (35). Measurement of VO2max was done by using the Bleep test and $\mathrm{HB}$ with the Hb test. Based on Kendall's tau non-parametric analysis, it is found that HB and VO2max are sufficiently correlated, so it is not certain that the higher the $\mathrm{HB}$ the higher the VO2max, although in the process of supplying energy these two variables are mutually supportive and relate.
\end{abstract}

Keywords: Hemoglobin; vo2max; game sport

d

https://doi.org/10.25299/sportarea.2021.vol6(2).6248

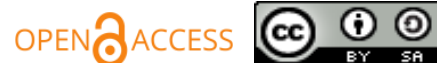

Copyright @ 2021 Isti Dwi Puspita Wati

Corresponding author: Isti Dwi Puspita Wati, Department of Sport Coaching, Faculty of Teacher Training and Education, Universitas Tanjungpura, Pontianak, Indonesia

Email: isti.dwi.puspita.w@ fkip.untan.ac.id

How to Cite: Wati, I. D. P. (2021). Are hemoglobin and volume oxygen maximum (vo2max) relevant each other?. Journal Sport Area, 6(2), 193-200. https://doi.org/10.25299/sportarea.2021.vol6(2).6248

\section{INTRODUCTION}

Each person's VO2max capacity varies. This is not immediately obtained. It takes regular exercise over a long period of time. While the adaptation of exercise with the adaptation of increasing VO2max for each individual is not the same (Joyner \& Lundby, 2018). It was found that performance and peak oxygen-using ability were related to VO2max ability (Decroix et al., 2016). The fact that long distance runners are dominated by runners from Kenya, the results of the study show that the work of the respiratory muscles is high and the body of Kenyan runners requires less energy in their work physiologically (Larsen \& Sheel, 2015).

Research conducted by Russians found that to determine a person's aerobic level can be predicted by looking at parental genes, a study was conducted on 230 Russian athletes and 1459 as controllers, a study was conducted using single-nucleotide polymorphisms (SNPs) (Ahmetov et al., 2015). Based on this research, it can explain that as one of the factors / variables to see the quality of athletes, it can be seen from the factors of parents. It cannot be concluded that if the parents are athletes, then their children are also athletes, but it is more understood that an athlete's child will tend to have the same potential as his parents. Various other studies have also been conducted such as block training did not increase VO2max (Manchado et al., 2018). Likewise, 
training with the traditional weight training system also cannot increase VO2max (Manchado et al., 2018). This research review concludes that not all exercises can increase VO2max, weight training with the block system training with the traditional system (Manchado et al., 2018), apparently unable to increase VO2max.

Physical activity for pleasure can actually improve physical fitness, reduce weight and increase VO2max, in postoperative patients who have not done physical activity for a long time (Tettero et al., 2018). In the next stage the results will be even greater after doing sports activities, especially on VO2max (Tettero et al., 2018). Futsal training by competing for 12 weeks $4 \mathrm{x}$ / week can actually increase your aerobic ability by more than 7\% (Barbieri et al., 2016). It turns out that based on the results of research on circulatory systems that are controlled with a homeistatic system, research on climbing athletes recommends training to increase aerobic capacity in the local arm and increase overall body eorobicness (Fryer et al., 2018). Climbing for 60 minutes 3 times as high as 8 weeks was found to increase VO2max (5.54\%, P <0.01) (Aras \& Akalan, 2016), after being monitored it turned out that this climb entered the intensity of $70 \%$. Based on this research review, it can be understood that the VO2max capability is general in nature and some is special. Improvement can be done in various ways, either by just doing physical activities (Tettero et al., 2018), playing futsal (Barbieri et al., 2016), or climbing walls (Aras \& Akalan, 2016). Being a key suggestion in the exercises given in this study is that the exercises are carried out continuously and regularly.

Based on a review of 53 international journal articles, it is stated that slow interval training ( $\leq 30 \mathrm{~s})$, low volume $(\leq 5 \mathrm{~min})$, and short-term exercise ( $\leq 4$ weeks) with high intensity is effective and efficient for increasing VO2Max (Wen et al., 2019). The next meta-analysis states that the maximum effect on VO2max is exercise with long intervals ( $\geq 2 \mathrm{~min}$ ), high volume ( $\geq 15 \mathrm{~min}$ ) and moderate exercise for ( $\geq 4-12$ weeks) with high and moderate intensity (Wen et al., 2019). VO2max correlates with the ability to do repetitive sprint training (Gharbi et al., 2015). Football players aged 16-18 years were tested with a cooper test, the average VO2max was 39.7 with a minimum of 35.7 and a maximum VO2max of 50.4 (Bramasko \& Kafrawi, 2016).

A review of the research conducted, agrees that VO2max is important, secondly, various efforts have been made to increase this ability, the three $\mathrm{VO} 2 \mathrm{max}$ affects the performance of athletes, the four various types of physical activity ranging from low to high intensity can be used to increase VO2max. In principle, VO2max is used to increase the ability to enter $\mathrm{O} 2$. Furthermore, this task was then taken over by HB. HB carries out its function as a carrier of oxygen in the blood. If anemia occurs, the number of HBs in the blood for boys and girls is below 13 and 12, this will lead to a decrease in aerobic gunsi (Baron et al., 2014; Musallam et al., 2011). Many factors appear to influence the amount of HB in the blood, including altitude, intensity, and duration of exercise, genetics, iron intake, history of disease. Based on the research, it is known that HB levels can be seen from the ability of VO2max (endurance) (Jacobs et al., 2011). So that data about the relationship between VO2max and HB is needed for the benefit of further training. The purpose of this study was to prove the relationship between $\mathrm{HB}$ and $\mathrm{VO} 2$ max.

\section{METHODS}

This research is a descriptive correlational study. The variables in this study were VO2max and hemoglobin. Samples were West Kalimantan PON athletes who were preparing to face PON Papua from the sport of games. The sports that were sampled in this study were 83 volleyball sand (6), badminton (17), Pentaque (12), table tennis (13), Futsal (35) with the number of male athletes 39 athletes and female athletes 44 athletes. Data were collected by performing tests and measurements of the sample. The test used to determine VO2 max capacity is the bleep test, while to find out HB with the HB test. Data were analyzed descriptively, and correlation.

\section{RESULTS AND DISCUSSIONS}

This research was conducted from May to September 2019, with the assistance of 12 students from the Tanjungpura University Sports Coaching study program as research assistants where the implementation of data collection was carried out in the KONI building in West Kalimantan. Athletes are tested first with an $\mathrm{Hb}$ test in the room then the VO2 max test is carried out in the field using the Bleep test. Further data can be seen in table 1. 
Table 1. Data Description of HB and VO2max

\begin{tabular}{ccccccc}
\hline & N & Minimum & Maximum & Mean & Std. Deviation \\
\hline HB & 83 & 10.00 & 20.60 & 14.1664 & 2.21133 \\
VO2max & 83 & 22.00 & 49.60 & 33.0000 & 7.58744 & \\
\hline
\end{tabular}

Based on table 1, it is found that the number of athletes measured in this study were 83 athletes who were sand volleyball (6), badminton (17), Pentaque (12), table tennis (13), Futsal (35). Obtained HB mean of athletes was 14.16 and VO2max 33.00. Looking at the VO2max data based on the mean and standard deviation of 7.58744, it can be seen that there is a wide range of VO2max altets in West Kalimantan. This can be seen from a minimum value of 22.00 to 49.00 .

Table 2. The Results of the Normality Test

\begin{tabular}{cccccccc}
\hline & \multicolumn{9}{c}{ Tests of Normality } & & \multicolumn{2}{c}{ Shapiro-Wilk } \\
\cline { 2 - 8 } & \multicolumn{4}{c}{ Kolmogorov-Smirnova } & Statistic & df & Sig. \\
\hline HB & .095 & 83 & .063 & .980 & 83 & .218 & .000 \\
VO2 maks & .159 & 83 & .000 & .923 & 83 & & \\
\hline
\end{tabular}

The HB data is normally distributed with a significance value of 0.063 , while VO2max is not normally distributed, but this is indicated by the number 0.000 . Furthermore, the analysis was continued with nonparametric statistics with the Kird Kendal test.

Table 3. Results of Non Parametric Correlation Test

\begin{tabular}{|c|c|c|c|c|}
\hline & & & HB & VO2 maks \\
\hline \multirow[t]{6}{*}{ Kendall's tau_b } & $\mathrm{HB}$ & Correlation Coefficient & 1.000 & $.484^{* *}$ \\
\hline & & Sig. (2-tailed) & 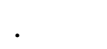 & .000 \\
\hline & & $\mathrm{N}$ & 83 & 83 \\
\hline & VO2 maks & Correlation Coefficient & $.484^{* *}$ & 1.000 \\
\hline & & Sig. (2-tailed) & .000 & . \\
\hline & & $\mathrm{N}$ & 83 & 83 \\
\hline
\end{tabular}

**. Correlation is significant at the 0.01 level (2-tailed).

Sources of data come from the same or paired data, so the analysis is suitable using Kendal tau. Unlike the non-parametric Kendall's tau correlation test, the correlation number is 0.484 with a significant count of 0.000 . If you look at these results, there is a correlation between HB and VO2max, but the correlation is here sufficient correlation. The results of this correlation can be stated as correlated but not high.

Based on the results of the study with a sample of 83 athletes, it was obtained data that the mean HB was 14.16 and VO2max was 33.00, the category for HB tended to be relatively normal and VO2max was in the low category. In terms of HB altet, West Kalimantan can be said to be safe, but from the side of VO2max it is still lacking. The logic is that a high VO2max will allow the body to have a large supply of oxygen. Physiologically, it remains only to see the next variable, namely whether the carrier (HB) is available in large quantities. The bigger carrier is the more $\mathrm{O} 2$ that can be caught. By capturing this $\mathrm{O} 2$ and vice versa, the process of removing $\mathrm{CO} 2$ as a residue from oxidation will also be easier and be faster so various efforts were made to increase these VO2max and HB levels. Various studies that have been carried out to increase VO2max can be classified into three groups, firstly low-intensity training, secondly high-intensity training, and the third training by playing according to the season. The next discussion is how the relationship between VO2max and HB. So that the next discussion is presented as follows:

\section{Low Intensity Exercise to Increase VO2max}

There is an effect of VO2max on the elderly by practicing the Rose Pencaksilat Jurus (Dahlan \& Patawari, 2019). By doing a healthy heart exercise for the elderly, it turns out that it can increase the heart's ability from 
$6.73 \mathrm{ml} / \mathrm{kg} /$ minute to $6.78 \mathrm{ml} / \mathrm{kg} /$ minute (Lengkong et al., 2016). There is a relationship between VO2max and the rate of decreased pulse rate (Hutama \& Yuliastrid, 2016). Fartlek training 3 times a week for 6 weeks can increase VO2max (Warni et al., 2017). 15 minutes of running exercise can increase VO2max (Artanty \& Lufthansa, 2017). Fartlek training is influential and can increase VO2max (Syaroni \& Kusuma, 2020).

\section{Exercise by Playing to Increase VO2max}

Training by participating in competitions, or making competitions or just playing, can actually increase VO2max ability, as evidence that training with small field games can actually increase VO2max $6.62 \%$ (Kusuma \& Purnomo, 2020) Training with 3vs3 small games increases VO2max 2 , 43\% and 4vs4 3.64\% (Puriana \& Kurniawan, 2019). Small side game exercises can increase VO2max (Syaroni \& Kusuma, 2020). Next is small sided game research, it turns out that it can also increase the VO2max ability of athletes aged 11-12 years (Rizaldi et al., 2019). Training with small side games has resulted in an increase in VO2max in U-17 soccer altets (Putra et al., 2016). If you look specifically at the exercises that are carried out, either by playing or by using small games, if analyzed then this training actually enters into high intensity. With small games or small fields, athletes are forced to move quickly and have less rest time. If the exercise is carried out in a competition or made a competition, if the player does not actively take part in the game then, the hypothesis of aerobic ability needs to be questioned.

\section{Exercise at High to Increase VO2max with High Intensity}

Reviews of studies have provided evidence that high-intensity exercise has a positive effect on VO2max. Exercise with the circuit method on students showed a 7.22\% increase in VO2max (Ashfahani, 2020). 8 weeks of High Intensity Interval Training can actually increase VO2max (Putra et al., 2017). The 12-minute CrossFit model of exercise can improve not only aerobics but also anaerobes (Bellar et al., 2015). TABATA training can significantly improve the VO2max ability of U_21 soccer athletes (Daya \& Palmizal, 2019). TABATA exercise can increase VO2max (Herlan \& Komarudin, 2020). Next to U-21 soccer athletes, training using TABATA has an effect on VO2max (Daya \& Palmizal., 2020). Interval training can increase VO2max (Yunus, 2017). Exercise with circuit training and interval training can actually increase VO2max (Prakoso \& Sugiyanto, 2017). The training exercise that is carried out is a high intensity exercise, convincingly that this high intensity has an influence on the ability of VO2max for the experimental person who is given the treatment. The clear mechanics of high intensity exercise, the heart lung and muscular system are forced to work hard, and one of the effects is oxygen debt. With this oxygen debt, in theory, exercise adaptation, there will be supercompensation, training that is carried out for a long time, eventually supercompensationsupercompensation will occur continuously and eventually there will be an increase in VO2max.

\section{$H B$ and $V O_{2} m a x$}

Red HB is the natural color of blood in which it contains iron which functions to bind $\mathrm{O} 2$ and $\mathrm{CO} 2$ (Sherwood, 2016). The positive logic is that HB and VO2max are closely related (Schmidt \& Prommer, 2010). There will be great advantages if $\mathrm{HB}$ and VO2max are high. There is evidence that athletes who are high in HB have good endurance (Malczewska-Lenczowska et al., 2016; Goodrich et al., 2018; Aryaputra et al., 2020).

The problem is how to increase HB by means of sports, previous research has not yet reached agreement on the one hand with training in the highlands (Neya et al., 2012) and (Wehrlin et al., 2016) with hypoxia exercises can increase HB, but on the other hand there is no change in HB (Du Bois et al., 2014) intermitten hypoxic training (Roczniok et al., 2011).

Meanwhile, based on the research that has been done, there is still little about how the exercise model increases HB. In essence, the exercise is hypoxic (a method of deliberately limiting oxygen intake). The reality in this study does not dare to declare conclusively that HB and VO2max have a close relationship, seeing that the resulting correlation value is still low. The existing research only states that the HB variable and VO2max have a positive relationship (Malczewska-Lenczowska et al., 2016; Goodrich et al., 2018; Aryaputra et al., 2020). 
The research literature provides recommendations for increasing HB by exercise by limiting oxygen intake, so that oxygen debt occurs and then by physiological adaptation of HB levels. Meanwhile, based on opinion (Otto, Montgomery, \& Richards, 2013). A person's fitness can be represented by the relationship between HB and $\mathrm{O} 2$ which is seen in fitness capacity, and this is proven by other studies (Malczewska-Lenczowska et al., 2016; Goodrich et al., 2018; Aryaputra et al., 2020).

\section{CONCLUSION}

Based on the data analysis, the conclusion in this study states that there is/is not a relationship between VO2max and HB. Based on the discussion and literature of this study, this is a strange thing. Considering that there is a physiological relationship between $\mathrm{HB}$ levels which function as a binder of $\mathrm{O} 2$ and $\mathrm{CO} 2$ in the process of the respiratory and oxidation chains with the $\mathrm{O} 2$ input expressed in VO2max. This study finally provides recommendations for the next experimental study by considering the effect of iron intake on HB increase compared with the treatment group that was given a placebo with an additional active treatment is exercise with a certain dose. This next study will answer the big question in the world of sports, how is the relationship between $\mathrm{HB}$ and VO2max.

\section{REFERENCES}

Ahmetov, I. I., Kulemin, N. A., Popov, D. V., Naumov, V. A., Akimov, E. B., Bravy, Y. R., Egorova, E. S., Galeeva, A. A., Generozov, E. V., Kostryukova, E. S., Larin, A. K., Mustafina, L. J., Ospanova, E. A., Pavlenko, A. V., Starnes, L. M., Zmijewski, P., Alexeev, D. G., Vinogradova, O. L., \& Govorun, V. M. (2015). Genome-wide association study identifies three novel genetic markers associated with elite endurance performance. Biology of Sport, 32(1), 3-9. https://doi.org/10.5604/20831862.1124568

Aras, D., \& Akalan, C. (2016). Sport climbing as a means to improve health-related physical fitness parameters. Journal of Sports Medicine and Physical Fitness, 56(11), 1304-1310.

Artanty, A., \& Lufthansa, L. (2017). Pengaruh Latihan Lari 15 Menit Terhadap Kemampuan VO2MAX. Jurnal Jendela Olahraga, 2(2), 9-19. https://doi.org/10.26877/jo.v2i2.1697

Aryaputra, A., Purwanto, B., \& Widodo, A. (2020). The Relationship Between Hemoglobin Concentration With Maximum Oxygen Volume Levels In Obese Female. STRADA Jurnal Ilmiah Kesehatan, 9(2), 450455. https://doi.org/10.30994/sjik.v9i2.295

Ashfahani, Z. (2020). Pengaruh Latihan Circuit Training Terhadap Daya Tahan Kardiovaskuler Pada Tim Futsal Universitas PGRI Semarang. Journal of Sport Coaching and Physical Education, 5(2), 63-67. https://doi.org/10.15294/jscpe.v5i2.36823

Barbieri, R. A., Zagatto, A. M., Milioni, F., \& Barbieri, F. A. (2016). Specific futsal training program can improve the physical performance of futsal players. Sport Sciences for Health, 12(2), 247-253. https://doi.org/10.1007/s11332-016-0283-z

Baron, D. M., Hochrieser, H., Posch, M., Metnitz, B., Rhodes, A., Moreno, R. P., Pearse, R. M., \& Metnitz, P. (2014). Preoperative anaemia is associated with poor clinical outcome in non-cardiac surgery patients. British Journal of Anaesthesia, 113(3), 416-423. https://doi.org/10.1093/bja/aeu098

Bellar, D., Hatchett, A., Judge, L. W., Breaux, M. E., \& Marcus, L. (2015). Herthe relationship of aerobic capacity, anaerobic peak power and experience to performance in CrossFit exercise. Biology of Sport, 32(4), 315-320. https://doi.org/10.5604/20831862.1174771 
Bramasko, I. S., \& Kafrawi, F. R. (2016). Menganalisis Vo 2 Max Melalui Cooper Test Pada Atlet Sepakbola Usia 16-18 Tahun di SSB Putras Jombang. Jurnal Kesehatan Olahraga, 4(4), 626-629.

Dahlan, F., \& Patawari, F. (2019). Meningkatkan Daya Tahan Kardiovaskular (Vo2max) Melalui Latihan Jurus Mawar Pencaksilat Pada Warga Lanjut Usia (Lansia) di Kecamatan Wara Timur Kota Palopo. Jurnal Pendidikan GLASSER. https://doi.org/10.32529/glasser.v3i1.187

Daya, W. J., \& Palmizal, A. (2019). Pengaruh Latihan Tabata Terhadap Kemampuan Vo2max Atlet Sepakbola Ps. Tungkal Ulu U-21. Multilateral Jurnal Pendidikan Jasmani dan Olahraga. https://doi.org/10.20527/multilateral.v18i2.7626

Decroix, L., De Pauw, K., Foster, C., \& Meeusen, R. (2016). Guidelines to classify female subject groups in sport-science research. International Journal of Sports Physiology and Performance, 11(2), 204-213. https://doi.org/10.1123/ijspp.2015-0153

Du Bois, A. M., Nelson, G. C., Ciccone, A. B., April, S. M., Thurston, T. S., Brown, L. E., Coburn, J. W., Galpin, A. J., \& Judelson, D. J. (2014). Effect Of Serial Apneas And Facial Immersion On High Intensity Aerobic Performance. Medicine \& Science in Sports \& Exercise. https://doi.org/10.1249/01.mss.0000495581.06853.6c

Fryer, S. M., Giles, D., Palomino, I. G., de la O Puerta, A., \& España-Romero, V. (2018). Hemodynamic and cardiorespiratory predictors of sport rock climbing performance. Journal of Strength and Conditioning Research, 32(12), 3534-3541. https://doi.org/10.1519/jsc.0000000000001860

Gharbi, Z., Dardouri, W., Haj-Sassi, R., Chamari, K., \& Souissi, N. (2015). Aerobic and anaerobic determinants of repeated sprint ability in team sports athletes. Biology of Sport, 32(3), 207-212. https://doi.org/10.5604/20831862.1150302

Goodrich, J., Ryan, B., \& Byrnes, W. (2018). The Influence of Oxygen Saturation on the Relationship Between Hemoglobin Mass and VO2max. Sports Medicine International Open, 2(4), E98-E104. https://doi.org/10.1055/a-0655-7207

Herlan, H., \& Komarudin, K. (2020). Pengaruh Metode Latihan High-Intensity Interval Training (Tabata) terhadap Peningkatan Vo2Max Pelari Jarak Jauh. Jurnal Kepelatihan Olahraga, 12(1), 11-17. https://doi.org/10.17509/jko-upi.v12i1.24008

Hutama, V. A., \& Yuliastrid, D. (2016). Hubungan Vo2max Terhadap Pemulihan Denyut Nadi Setelah Latihan Submaksimal Pada Pemain Sepakbola Putra Kelompok Usia 18 Tahun El Faza Fc Surabaya. Jurnal Kesehatan Olahraga, 5(2), 71-78.

Jacobs, R. A., Rasmussen, P., Siebenmann, C., Díaz, V., Gassmann, M., Pesta, D., Gnaiger, E., Nordsborg, N. B., Robach, P., \& Lundby, C. (2011). Determinants of time trial performance and maximal incremental exercise in highly trained endurance athletes. Journal of Applied Physiology, 111(5), 1422-1430. https://doi.org/10.1152/japplphysiol.00625.2011

Joyner, M. J., \& Lundby, C. (2018). Concepts about VO2max and Trainability Are Context Dependent. Exercise and Sport Sciences Reviews, 46(3), 138-143. https://doi.org/10.1249/JES.0000000000000150

Kusuma, E. T., \& Purnomo, M. (2020). Pengaruh Latihan Small Sided Games Terhadap Peningkatan Vo2max Peserta Ekstrakulikuler Futsal Smp Labschool Unesa. Jurnal Prestasi Olahraga, 3(1), 1-6. 
Larsen, H. B., \& Sheel, A. W. (2015). The Kenyan runners. Scandinavian Journal of Medicine and Science in Sports, 25(S4), 110-118. https://doi.org/10.1111/sms.12573

Lengkong, G., Marunduh, S. R., \& Wungow, H. I. S. (2016). Pengaruh senam bugar lansia terhadap kebugaran jantung paru di Panti Werdha Bethania Lembean. Jurnal E-Biomedik, 4(2). https://doi.org/10.35790/ebm.4.2.2016.14014

Malczewska-Lenczowska, J., Orysiak, J., Majorczyk, E., Zdanowicz, R., Szczepańska, B., Starczewski, M., Kaczmarski, J., Dybek, T., Pokrywka, A., Ahmetov, I. I., \& Sitkowski, D. (2016). Total hemoglobin mass, aerobic capacity, and hbb gene in polish road cyclists. Journal of Strength and Conditioning Research, 30(12), 3512-3519. https://doi.org/10.1519/JSC.0000000000001435

Manchado, C., Cortell-Tormo, J. M., \& Tortosa-Martínez, J. (2018). Effects of two different training periodization models on physical and physiological aspects of elite female team handball players. Journal of Strength and Conditioning Research, 32(1), 280-287. https://doi.org/10.1519/JSC.0000000000002259

Musallam, K. M., Tamim, H. M., Richards, T., Spahn, D. R., Rosendaal, F. R., Habbal, A., Khreiss, M., Dahdaleh, F. S., Khavandi, K., Sfeir, P. M., Soweid, A., Hoballah, J. J., Taher, A. T., \& Jamali, F. R. (2011). Preoperative anaemia and postoperative outcomes in non-cardiac surgery: A retrospective cohort study. The Lancet, 378(9800), 1396-1407. https://doi.org/10.1016/S0140-6736(11)61381-0

Neya, M., Enoki, T., Ohiwa, N., Kawahara, T., \& Gore, C. J. (2012). Ten Hours Nightly Simulated Altitude at $3000 \mathrm{~m}$ Increases Hemoglobin Mass and VO2max. Int J Sports Physiol Perform, 8(4), 366-372.

Otto, J. M., Montgomery, H. E., \& Richards, T. (2013). Haemoglobin concentration and mass as determinants of exercise performance and of surgical outcome. Extreme Physiology and Medicine, 2(33), 1-8. https://doi.org/10.1186/2046-7648-2-33

Palmizal, A., Munar, H., \& Pasaribu, A. M. N. (2020). Kemampuan Vo2max Atlet Sepakbola Ditinjau dari Latihan Tabata. Journal Coaching Education Sports, 1(1), 27-36. https://doi.org/10.31599/jces.v1i1.83

Prakoso, G. P. W., \& Sugiyanto, F. (2017). Pengaruh metode latihan dan daya tahan otot tungkai terhadap hasil peningkatan kapasitas VO2Max pemain bola basket. Jurnal Keolahragaan, 5(2), 151-160. https://doi.org/10.21831/jk.v5i2.10177

Puriana, R. H., \& Kurniawan, D. (2019). Pengaruh Latihan Small Sided Games 3v3 dan 4v4 Terhadap Peningkatan VO2max Atlet Futsal di Lamongan. Jurnal Pendidikan Jasmani, 2(1), 187-193.

Putra, A. U. K., Sudjana, I. N., \& Amiq, F. (2016). Pengaruh Latihan Small Sided Games Terhadap Peningkatan Kemampuan Vo2Max Pemain Sepakbola U-17 di Persatuan Sepakbola Smuba Junior Kota Batu. Jurnal Pendidikan Jasmani, 25(1), 20-30. http://dx.doi.org/10.17977/pj.v25i1.488620-30

Putra, K. P., Al Ardha, M. A., Kinasih, A., \& Aji, R. S. (2017). Korelasi perubahan nilai VO2max, eritrosit, hemoglobin dan hematokrit setelah latihan high intensity interval training. Jurnal Keolahragaan, 5(2), 161-170. https://doi.org/10.21831/jk.v5i2.14875

Rizaldi, G., Yunus, M., \& Supriyadi, S. (2019). Pengaruh Latihan Small Sided Game Terhadap Peningkatan Vo2max Pada Pemain Sekolah Sepakbola (SSB) Iguana Kicker Club (IKC) FC Usia 11-12 Tahun. Jurnal Sport Science, 9(1), 30-38. https://doi.org/10.17977/um057v9i1p30-38 
Roczniok, R., Czuba, M., Waskiewicz, Z., Zajac, A., Poprzecki, S., Cholewa, J., \& Roczniok, R. (2011). The effects of intermittent hypoxic training on aerobic capacity and endurance performance in cyclists. Journal of Sports Science and Medicine, 10(1), 175-183.

Schmidt, W., \& Prommer, N. (2010). Impact of alterations in total hemoglobin mass on VO2max. Exercise and Sport Sciences Reviews, 38(2), 68-75. https://doi.org/10.1097/JES.0b013e3181d4957a

Sherwood, L. (2016). Human Physiology From Cells to Systems (Ninth Edition). Boston, MA: Cengage Learning.

Syaroni, F. D., \& Wijaya Kusuma, I. D. M. A. (2020). Perbandingan Fartlek dan Small Side Games Untuk Meningkatkan Vo2max Pada Siswa Ekstrakurikuler. JSES: Journal Of Sport And Exercise Science, 3(1), 37-41. https://doi.org/10.26740/jses.v3n1.p37-41

Tettero, O. M., Aronson, T., Wolf, R. J., Nuijten, M. A. H., Hopman, M. T. E., \& Janssen, I. M. C. (2018). Increase in Physical Activity After Bariatric Surgery Demonstrates Improvement in Weight Loss and Cardiorespiratory Fitness. Obesity Surgery, 28(12), 3950-3957. https://doi.org/10.1007/s11695-018$3439-x$

Warni, H., Arifin, R., \& Bastian, R. A. (2017). Pengaruh Latihan Daya Tahan (Endurance) Terhadap Peningkatan Vo2max Pemain Sepakbola. Multilateral Jurnal Pendidikan Jasmani dan Olahraga, 16(2), 121-126. https://doi.org/10.20527/multilateral.V16i2.4248

Wehrlin, J. P., Marti, B., \& Hallén, J. (2016). Hemoglobin mass and aerobic performance at moderate altitude in elite athletes. Advances in Experimental Medicine and Biology, 903, 357-374. https://doi.org/10.1007/978-1-4899-7678-9_24

Wen, D., Utesch, T., Wu, J., Robertson, S., Liu, J., Hu, G., \& Chen, H. (2019). Effects of different protocols of high intensity interval training for VO2max improvements in adults: A meta-analysis of randomised controlled trials. Journal of Science and Medicine in Sport, 22(8), 941-947. https://doi.org/10.1016/j.jsams.2019.01.013

Yunus, M. (2017). Pengaruh Latihan Interval Terhadap Kenaikan Jumlah Sel Eritrosit dan VO2Max. Motion: Jurnal Riset Physical Education, 8(1), 79-89. 